\title{
Groundwater as an emergency source for drought mitigation in the Crocodile River catchment, South Africa
}

\author{
F. E. F. Mussá ${ }^{1,2}$, Y. Zhou ${ }^{1}$, S. Maskey ${ }^{1}$, I. Masih ${ }^{1}$, and S. Uhlenbrook ${ }^{1,3}$ \\ ${ }^{1}$ UNESCO-IHE, Institute for Water Education, P.O. Box 3015, 2601 DA Delft, the Netherlands \\ ${ }^{2}$ Eduardo Mondlane University, Faculty of Engineering, Av. de Moçambique km 1.5, C. Postal 257, Maputo, Mozambique \\ ${ }^{3}$ Delft University of Technology, Section of Water Resources, P.O. Box 5048, 2600 GA Delft, the Netherlands \\ Correspondence to: F. E. F. Mussá (fatima_mussa@live.com) and Y. Zhou (y.zhou@unesco-ihe.org)
}

Received: 31 January 2014 - Published in Hydrol. Earth Syst. Sci. Discuss.: 6 March 2014

Revised: 25 December 2014 - Accepted: 29 January 2015 - Published: 26 February 2015

\begin{abstract}
Global climate change has received much attention worldwide in the scientific as well as in the political community, indicating that changes in precipitation, extreme droughts and floods may increasingly threaten many regions. Drought is a natural phenomenon that causes social, economical and environmental damage to society. In this study, we assess the drought intensity and severity and the groundwater potential to be used as a supplementary source of water to mitigate drought impacts in the Crocodile River catchment, a water-stressed sub-catchment of the Incomati River catchment in South Africa. The research methodology consists of three parts. First, the spatial and temporal variation of the meteorological and hydrological drought severity and intensity over the catchment were evaluated. The Standardized Precipitation Index (SPI) was used to analyse the meteorological drought and the Standardized Runoff Index (SRI) was used for the hydrological drought. Second, the water deficit in the catchment during the drought period was computed using a simple water balance method. Finally, a groundwater model was constructed in order to assess the feasibility of using groundwater as an emergency source for drought impact mitigation. Results show that the low-rainfall areas are more vulnerable to severe meteorological droughts (lower and upper crocodile). Moreover, the most water stressed subcatchments with high level of water uses but limited storage, such as the Kaap located in the middle catchment and the Lower Crocodile sub-catchments, are more vulnerable to severe hydrological droughts. The analysis of the potential groundwater use during droughts showed that a deficit of $97 \mathrm{Mm}^{3} \mathrm{yr}^{-1}$ could be supplied from groundwater without considerable adverse impacts on the river base flow and
\end{abstract}

groundwater storage. Abstraction simulations for different scenarios of extremely severe droughts reveal that it is possible to use groundwater to cope with the droughts in the catchment. However, local groundwater exploitation in Nelspruit and White River sub-catchment will cause large drawdowns (>10 m) and high base flow reduction (>20\%). This case study shows that conjunctive water management of groundwater and surface water resources is necessary to mitigate the impacts of droughts.

\section{Introduction}

Global climate change is one of the serious environmental challenges which the world is facing this century (IPCC, 2013). It is related to systematic changes of the entire world's weather and climate patterns beyond the natural variability limits, and increased droughts are among the consequences. Drought is a natural phenomenon that may cause serious social, economical and environmental damage, in particular in areas where the water resources are already highly utilized. A number of different reactive and proactive measures on regional or national scale can be used to reduce its impacts. These measures include: the use of resilience buildings of rain-fed farming system for water harvesting for supplemental irrigation in semi-arid regions (Rockström, 2003); the use of groundwater, use of storage in mountain rivers where precipitation is higher, and the construction of water distribution and water storage systems (MacDonald, 2007); and the artificial groundwater recharge with excess water from wet periods and reuse of treated wastewater (Zhou et al., 2011). 
Along the same lines, Pavelic et al. (2012) propose capturing the peak flow (surplus of water) during the wet season and recharging shallow alluvial aquifers in a distributed manner upstream of the flood-prone areas. Two large regional projects have been conducted in Africa to investigate the groundwater potential for water supply during drought. The Groundwater and Drought Management Project (SADC, http://archive.iwlearn.net/www.sadc-groundwater.org/) has developed strategic regional approaches to support and enhance the capacity of the Southern African Development Community in the definition of drought management policies, specifically in relation to the role, availability and supply potential of groundwater resources. Groundwater Resources Investigation for Drought Mitigation in Africa Programme (GRIDMAP, http://www.unesco.org/new/fileadmin/ MULTIMEDIA/FIELD/Nairobi/pdf/GRIDMAPFlyer.pdf) aimed at assessing the availability of groundwater resources in the Horn of Africa and determining how much groundwater resources can be utilized safely for emergency and long-term development demands.

The Incomati river catchment is a transboundary river catchment located in the southeastern part of Africa which flows through South Africa, Swaziland and Mozambique and discharges into the Indian Ocean. The river catchment is characterized as a semi-arid climate subject to hydrological extremes: severe droughts and floods. The Crocodile River is one of the most important tributaries of Incomati. In the Crocodile catchment, data and knowledge are limited regarding the groundwater resources and its potential for use during the drought period. One of the first attempts to provide maps of sustainable groundwater harvest potential (GHP) was by Baron et al. (1998), which was based on hydrogeological maps developed by Vegter (1995). The GHP maps cover the whole South Africa and provide a first estimate of the maximum mean annual amount of water that can be abstracted from groundwater without depleting the aquifers. However, the use of these maps for local groundwater management planning is limited due to high uncertainty. The GHP maps were updated by Water Systems Management (2001) and DWAF (2006). However, the update in the part of the Incomati catchment is largely based on interpolation from some experimental data from the surrounding catchments, thus associated with high uncertainty.

Some groundwater studies have been carried out recently in the Incomati catchment. Consultec and BKS (2001) quantified groundwater availability in the Incomati catchment aiming to assess its potential contribution to the total water resources of the catchment. Tanner and Mauritius (2010) made a groundwater potential assessment study for the whole Incomati catchment based on the aquifer classifications suggested by DWAF (2006). Their study produced maps of the Incomati groundwater availability (in terms of low, medium or high water availability) and the average well yield of Incomati, without distinction between wet and dry periods. Some groundwater studies have been done in the Kruger Na- tional Park, a conservation area partly located in the Lower Crocodile (Fundisi et al., 2012; Niekerk et al., 2012; Fischer et al., 2009, 2010; Leyland and Witthüser, 2008). So far, many of the groundwater potential assessment studies have been performed at a large scale, but no groundwater potential assessment study has been carried out in the Crocodile River catchment.

Due to the intense agricultural activity, the Crocodile River catchment is highly water stressed. The surface water is insufficient to meet the demands especially during drought periods. Small-scale farmers are the most vulnerable and affected by drought hazards. The downstream country Mozambique is also highly affected when droughts occur in this catchment because of reduced transboundary flows (Zaag and Vaz, 2003). In order to mitigate and manage water shortage during droughts, measures are being taken on the catchment scale. These measures include water transfer from adjacent catchments (Sabie and Komati) into the Crocodile River catchment, storage in reservoirs, water restrictions to avoid system failure and simple management models being setup to quantify the risks (Tanner and Mauritius, 2010). Although groundwater is used locally, it is not a main component of the actual drought mitigation and management plan. However, groundwater has been considered as a potential source to mitigate the impact of droughts and help to meet future increased water demand in the region (DWA, 2013).

Given the vulnerability of the Crocodile catchment to climate change, the necessity of further expanding agricultural activities and lack of knowledge on groundwater availability in drought periods, research on drought and the feasibility of using groundwater as an emergency source to mitigate its impacts is of great importance. The specific objectives of this study are: (i) classifying spatially the meteorological and hydrological droughts in terms of intensity and severity, (ii) assessing the water availability versus demand in the catchment during the drought periods, and (iii) formulating drought mitigation strategies by assessing the groundwater availability during drought periods.

\section{Material and methods}

\subsection{Study area}

The Crocodile River catchment has an area of around $10446 \mathrm{~km}^{2}$ and presents a wide range of elevation varying from around $2030 \mathrm{~m}$ in the most upstream part and gradually decreasing to $140 \mathrm{~m}$ at the outlet (Fig. 1). The main economic activities in the catchment are agriculture and forestry, with urban development and mining activities occupying a secondary role. According to the Incomati Water Availability Assessment Study (DWAF, 2009) the total area of irrigated agriculture and commercial forestry in the Crocodile catchment was $2452 \mathrm{~km}^{2}$ in 2004 which corresponds to around 


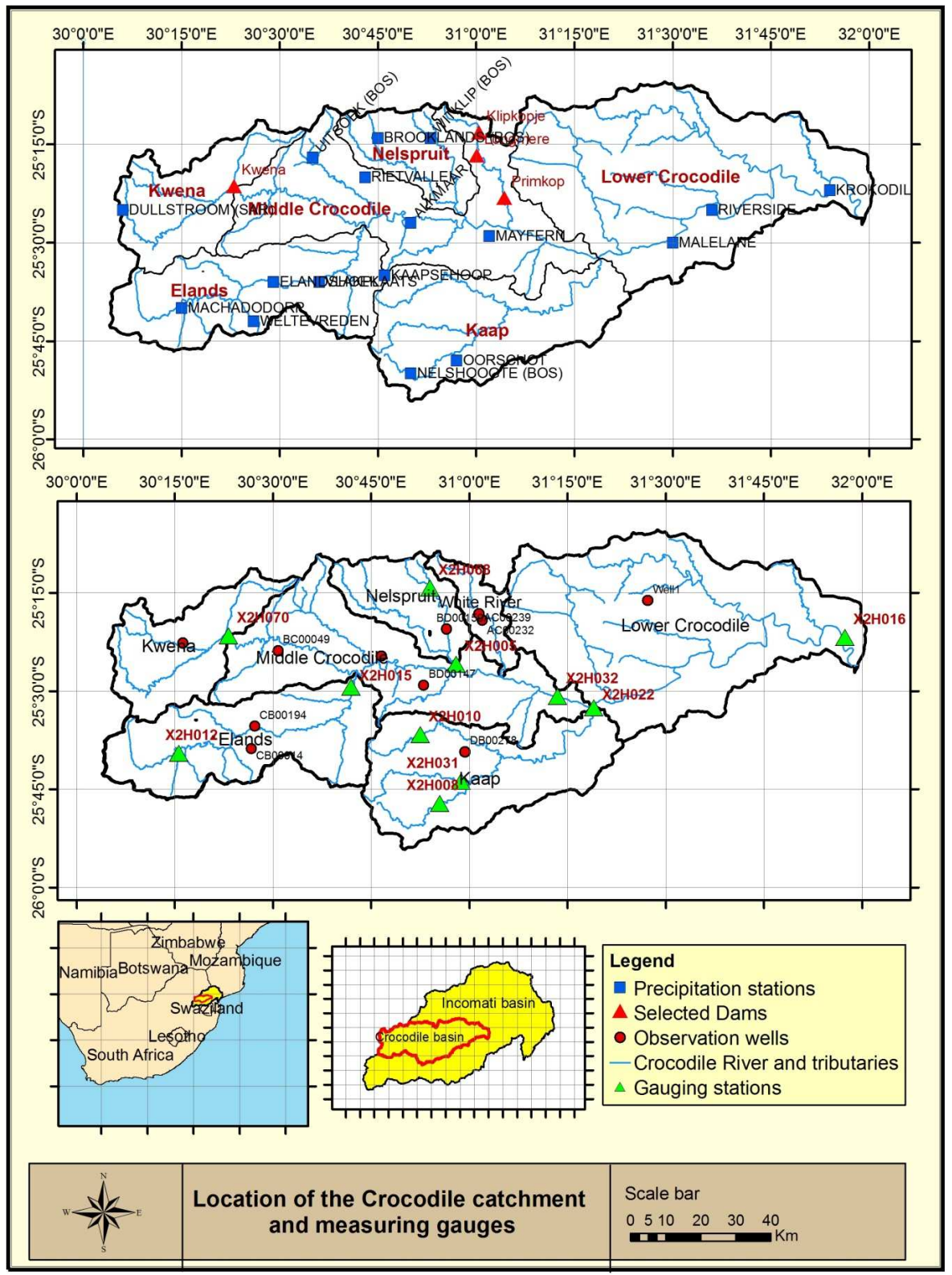

Figure 1. Location of precipitation gauges, discharge stations, observation boreholes and catchment division in sub-catchments.

$61 \%$ of the total irrigated area in the whole Incomati catchment.

The catchment is characterized by semi-arid climate with an annual rainfall and potential evaporation of 850 and $1380 \mathrm{~mm} \mathrm{yr}^{-1}$, respectively. The precipitation is highly seasonal; more than $80 \%$ of the annual rainfall falls during the summer half-year October-March. The precipitation also varies over the catchment, is higher in the middle part of the catchment where there are mountains and lower in the upstream and downstream regions. Potential evaporation decreases from downstream (low altitudes) to upstream (high altitudes).
The geology of the Crocodile catchment is complex. Around $60 \%$ of the total area (in the middle and lower regions) consists mainly of granite and gneiss. It is characterized in the south by sedimentary rocks (such as arenite) and volcanic rocks (mainly lavas) of the Barberton sequence. In the west it is composed of a complex mixture of sedimentary rocks (such as arenite and shale), volcanic (mainly andesite) and dolomitic rocks of the Transvaal sequence. In the east it contains a very small area of sedimentary rocks (such as shale) and volcanic rocks (mainly basalt and rhyolite) of the Karoo sequence. The aquifers of the Crocodile catchment mostly consist of regolith materials. 
Table 1. List of data sets used.

\begin{tabular}{|c|c|c|c|c|}
\hline Station name & Station number & Start year & End year & $\begin{array}{r}\% \text { of } \\
\text { missing data }\end{array}$ \\
\hline \multicolumn{5}{|c|}{ Precipitation stations } \\
\hline Alkmaar & $0555567 \mathrm{~W}$ & 1940 & 2012 & 0.0 \\
\hline Oorschot & $0518859 \mathrm{~W}$ & 1940 & 2000 & 0.0 \\
\hline Elandshoek & $0517816 \mathrm{~W}$ & 1940 & 2000 & 3.3 \\
\hline Rietvallei & $0555441 \mathrm{~W}$ & 1940 & 2001 & 5.0 \\
\hline Machadodorp & $0517430 \mathrm{~W}$ & 1940 & 2012 & 11.1 \\
\hline Kaapsehoop & $0518455 \mathrm{~W}$ & 1940 & 2000 & 28.3 \\
\hline Vlakplaats & $0518186 \mathrm{~W}$ & 1940 & 2001 & 4.9 \\
\hline Dullstroom & $0554175 \mathrm{~W}$ & 1940 & 2000 & 0.0 \\
\hline Mayfern & $0556088 \mathrm{~W}$ & 1940 & 2012 & 9.7 \\
\hline Weltevreden & $0517762 \mathrm{~W}$ & 1940 & 2012 & 4.2 \\
\hline Nelshoogte & $0518589 \mathrm{~W}$ & 1940 & 2012 & 4.2 \\
\hline Brooklands & $0555405 \mathrm{~W}$ & 1940 & 2012 & 1.4 \\
\hline Riverside & $0557115 \mathrm{~W}$ & 1940 & 2000 & 3.3 \\
\hline Witklip & $0555673 \mathrm{~W}$ & 1940 & 2012 & 0.0 \\
\hline Malelane & $0556898 \mathrm{~W}$ & 1940 & 2000 & 0.0 \\
\hline Krokodilbrug & $0557712 \mathrm{~W}$ & 1940 & 2012 & 0.0 \\
\hline Uitsoek & $0555137 \mathrm{~W}$ & 1940 & 2012 & 16.7 \\
\hline \multicolumn{5}{|c|}{ Discharge stations } \\
\hline Boschrand & $\mathrm{X} 2 \mathrm{H} 005$ & 1960 & 2012 & 0.0 \\
\hline Sassenheim & Х2H008 & 1948 & 2012 & 2.8 \\
\hline Bellevue & $\mathrm{X} 2 \mathrm{H} 010$ & 1948 & 2012 & 0.0 \\
\hline Geluk & X2H012 & 1956 & 2012 & 0.0 \\
\hline Lindenau & Х2H015 & 1959 & 2012 & 4.9 \\
\hline Ten Bosch & Х2H016 & 1960 & 2012 & 3.5 \\
\hline Dolton & X2H022 & 1960 & 2012 & 7.5 \\
\hline Bornmans Drift & $\mathrm{X} 2 \mathrm{H} 031$ & 1966 & 2012 & 5.9 \\
\hline Weltevrede & $\mathrm{X} 2 \mathrm{H} 032$ & 1968 & 2012 & 3.1 \\
\hline Witklip Dam & X2H068 & 1969 & 2012 & 0.0 \\
\hline Kwena Dam & $\mathrm{X} 2 \mathrm{H} 070$ & 1979 & 2012 & 0.0 \\
\hline
\end{tabular}

\subsection{Data sets}

Lynch (2003) developed a rainfall database of the South African region with data starting from around 1900 and ending in 2001. The database consists of daily precipitation records and data quality control gathered from the three main custodians of rainfall data in South Africa which include: SAWS (South Africa Weather Service), SASRI (South Africa Sugarcane Research Institution) and ARC (Agricultural Research Council). Additionally, a large number of municipalities, private companies and individuals in South Africa also contributed with rainfall data to the database. Lynch (2003) computed the percentage of non-missing data of the time series for each station.

Data from this database were used and from 2001 onwards, data provided only by SAWS were used. 17 precipitation stations with low percentage of missing data (Table 1) and a good spatial variability (Fig. 1) were selected. The time period for less missing data corresponds to the period of 1940 to 2011. Similarly, 11 gauging stations of river discharges were selected based on the length of the time series (at least 30 years of data), missing data in the time series (Table 1) and spatial variability of the stations (Fig. 1).

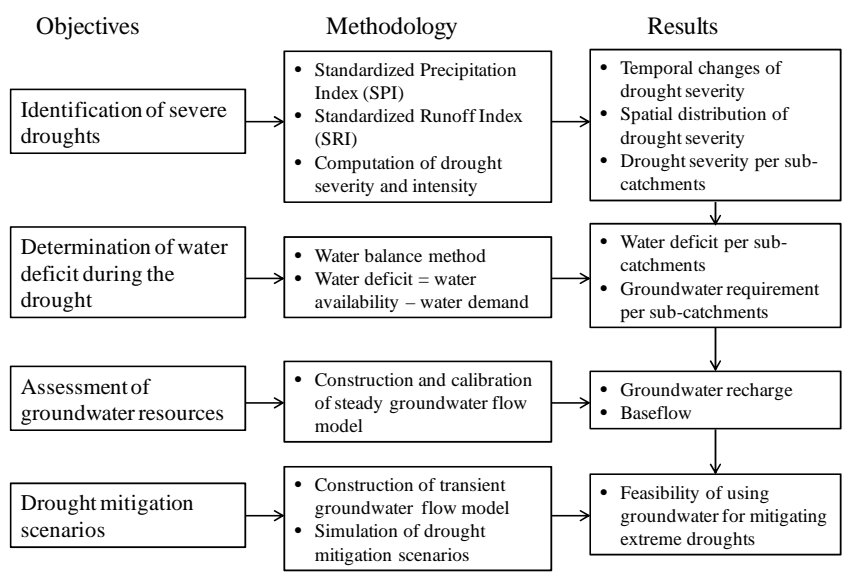

Figure 2. Research methodology.

The Crocodile catchment has around 320 groundwater wells operated by DWA. Around $25 \%$ of the wells do not have any water level measurement. Furthermore, there is only one water level measurement per year in almost all the wells. Only a few wells have time series of water levels which covers the period from 2000 onwards. Moreover, not many wells have water level measurements in the severe drought periods, especially in the Lower Crocodile. Thus, only 10 wells with water level measurements during drought periods were available for the model calibration (Fig. 1).

A land use map was acquired from the Department of Water Affairs (DWA) in South Africa. Reference evapotranspiration data for each sub-catchment were obtained from the DWA study (DWAF, 2009). Topography data consist of $90 \times 90 \mathrm{~m}^{2}$ digital elevation model (DEM) of Shuttle Radar Topography Mission (SRTM) from NASA. Hydrogeological characteristics were obtained from a simplified hydrogeological map from the Council of Geosciences of South Africa (see Fig. 1). Aquifer parameters such as layers thickness and hydraulic conductivity were provided by the Water Resources of South Africa study (WRC, 2005). Due to the lack of data, the values of specific yield were assigned to the geological formations based on general knowledge available in the literature, for instance, Nonner (2010).

\subsection{Methods}

An overview of the methodology used in this study is presented in Fig. 2. The methodology consists of drought classification, water deficit assessment during drought periods, and groundwater modelling for analysing groundwater potential for drought mitigation.

\subsubsection{Drought classification}

Droughts can be defined as "a decrease of water availability to substantially below the normal condition for a certain place and time" (Loucks and Beek, 2005) and are usually 
Table 2. SPI or SRI classes.

\begin{tabular}{ll}
\hline SPI or SRI range & Classification \\
\hline SPI or SRI $\leq-2.0$ & Extremely dry \\
$-2.0<$ SPI or SRI $\leq-1.5$ & Severely dry \\
$-1.5<$ SPI or SRI $\leq-1.0$ & Moderately dry \\
$-1.0<$ SPI or SRI $\leq 1.0$ & Near normal \\
$1.0<$ SPI or SRI $\leq 1.5$ & Moderately wet \\
$1.5<$ SPI or SRI $\leq 2.0$ & Severely wet \\
SPI or SRI $\geq 2.0$ & Extremely wet \\
\hline
\end{tabular}

Source: Sienze and Jahnke-Bornemann (2012).

classified as meteorological, hydrological and agricultural droughts. In this research, we focus on meteorological and hydrological droughts. Several drought indices can be used to identify droughts (Werick et al., 1994; Baykan and Özçelik, 2006; Palmer, 1965, 1968; Willeke, 1994; McKee et al., 1993; Shukla and Wood, 2008). Furthermore, droughts can be classified according to its duration, severity and intensity. Drought duration is the time during which a drought index remains below a certain critical value, whereas drought severity is represented as the cumulative of a drought index below a critical value within the drought duration and drought intensity as the average of the drought index over the drought duration (Mishra and Singh, 2010). Comparison of the advantages, disadvantages and applicability of the various drought indices has been reported in the literature (Loucks and Beek, 2005; Zargar et al., 2011; Mishra and Singh, 2010; Guttman, 1998; Sims et al., 2002). In this study, we applied the commonly used Standardized Precipitation Index (SPI) (McKee et al., 1993) and Standardized Runoff Index (SRI) (Shukla and Wood, 2008) to analyse meteorological droughts and hydrological droughts, respectively. Both SPI and SRI can be expressed on different timescales, e.g. 3 months, 6 months and 12 months. Table 2 shows how an event can be classified according to the SPI and SRI values.

First, we calculated 12-month SPI for 17 precipitation stations and 12-month SRI for 12 discharge stations for the period from 1940 to 2011. Then, for each severe drought with SPI or SRI values -1.5 or below, we determined severity and intensity of both meteorological and hydrological droughts. A threshold value of -1 (SPI or SRI) was used to define a drought event (beginning and ending of a drought).

From the drought severity calculated for each rainfall station, we derived average severity of meteorological drought for each sub-catchment based on the Thiessen polygons method. The hydrological drought severity for each subcatchment corresponds to the drought severity of the discharge station at the outlet of that sub-catchment.

Furthermore, the most severe drought was selected to show the variability of the drought severity and intensity over the catchment. For this drought, the drought severity and intensity was determined for each precipitation station. Krig- ing interpolation (Matheron, 1963) was used to produce the meteorological drought severity contour map over the catchment.

\subsubsection{Water deficit during drought period}

For the water deficit computation, the catchment was divided into seven main sub-catchments (see Fig. 1). The water deficit per sub-catchment during a drought was computed as the water availability minus the water requirements. The water availability was considered to be the natural flow of the river computed by DWAF (2009) minus the stream flow reduction due to the forestry water use.

The main water requirements in the Crocodile catchment include irrigation, domestic and industrial supply, and a minimum transboundary flow, which is the agreed minimum discharge that has to be released to the Mozambican territory. Irrigation constitutes the principal water demand. Domestic and industrial water requirements were provided by DWAF (2009) study and the minimum transboundary flow of $0.9 \mathrm{~m}^{3} \mathrm{~s}^{-1}$ was obtained from the Water Use Agreement signed between Mozambique, Swaziland and South Africa (TPTC, 2002). Irrigation water requirements were computed based on the FAO's recommendations (FAO, 1997). The effective precipitation, i.e. the precipitation available in the soil for the plants, is one of the necessary components for the irrigation water requirement computation. We computed the effective precipitation based on a fixed percentage approach (Smith, 1988). It consists of determining the $80 \%$ probable rainfall $\left(\mathrm{P}_{80}\right)$ and correcting for possible outfluxes due to runoff and percolation. As the main focus of this paper is to compute the irrigation requirements for the worst drought, instead of using the $\mathrm{P}_{80}$, the average observed precipitation during the drought period was used which is close to the $\mathrm{P}_{70}$.

\subsubsection{Groundwater modelling to develop a drought mitigation strategy}

A numerical groundwater model was constructed to assess groundwater potential during the drought period and to simulate the impacts of groundwater abstraction on the storage, water levels and base flow reduction in the river. The most severe drought observed within the study period was selected. The groundwater model is based on the widely used modelling software MODFLOW (McDonald and Harbaugh, 1983). First, a steady-state model was constructed, with the objective of determining the initial conditions for the transient model. Second, a simplified transient natural model was built with recharge on a monthly scale representing the average monthly recharge for the drought period. The model consists of one layer representing the weathered and fractured rocks. A model grid cell of $1 \times 1 \mathrm{~km}^{2}$ was used, in line with the coarse spatial data sets available. The river catchment boundary was defined as the model boundary, given the 
Table 3. Water transfer in the Crocodile catchment.

\begin{tabular}{llr}
\hline Transfer from & Transfer to & $\begin{array}{r}\text { Amount transfer } \\
\left(\mathrm{Mm}^{3} \mathrm{yr}^{-1}\right)\end{array}$ \\
\hline Nelspruit & White River & 3.0 \\
Sabie and Lomati* & Kaap & 8.5 \\
Middle Crocodile & Lower Crocodile & 25.6 \\
Sabie and Lomati* & Lower Crocodile & 6.0 \\
\hline
\end{tabular}

Source: DWAF (2009); * outside the Crocodile.

fact that the shallow groundwater flow is mainly discharged to the rivers in the catchment.

Initial values of the recharge to the groundwater from the sub-catchments were computed by using the Thornthwaite water balance model from the US Geological Survey (McCabe and Markstrom, 2007). The water balance model was calibrated using the available river discharge data from several sub-catchments.

The MODFLOW Evaporation package parameters were determined for each sub-catchment. The evaporation surface is the same as surface elevation of the catchment. An extinction depth of $5 \mathrm{~m}$, the average root depth of pine and eucalypt trees (Alliance, 2002), was assigned for the forestrydominated sub-catchments, namely Nelspruit, White River, Elands and Kaap sub-catchments; the depth of $2 \mathrm{~m}$, the average root depth of grass roots under semi-arid conditions (Murphy, 2010), was assigned for Kwena, Middle Crocodile and Lower Crocodile sub-catchments which are mainly covered by savannas. The reference evaporation provided by DWAF (2009) is assigned as the maximum rate of evaporation. The River package was used to simulate groundwater discharges to rivers as base flow. Finally, the model was calibrated in the steady state manually to adjust the groundwater recharge using the available observed groundwater levels and the river discharges.

\subsection{Scenarios using groundwater as an emergency source}

As the objective here is to use the groundwater only as an emergency source, the existing drought mitigation strategy of the catchment was taken into account for the computation of the groundwater abstraction needs. The existing drought mitigation strategy comprises the storage of surplus water (during the wet season) in dams and water transfers within the catchment and from out of the catchment (Table 3). Only the storage of the major dams (storage capacity $>1.0 \mathrm{Mm}^{3}$ ) are considered - these dams are Kwena, Klipkopje, Longmere and Primkop dams with full storage capacities of 158.9, 11.9, 4.3 and $2 \mathrm{Mm}^{3}$, respectively.

It was assumed that the surplus water of the wet season would be stored in dams and further used in the dry period. This useful water surplus (UWS) was obtained by subtracting evaporation from the dams from the water surplus and
Table 4. Abstractions simulation scenarios.

\begin{tabular}{lll}
\hline Scenarios & Recharge & Wells abstraction \\
\hline Simulation 1 & Reduced in 10\% & Increased in 10\% \\
Simulation 2 & Reduced in 25\% & Increased in 25\% \\
Simulation 3 & Reduced in 50\% & Increased in 50\% \\
Simulation 4 & Reduced in 50\% & Increased in 100\% \\
\hline
\end{tabular}

applying a reduction factor of 0.7 to take into account the losses in the river channel. Thus, for each sub-catchment, the groundwater abstraction need was computed using

$\mathrm{GWN}=\mathrm{WD}_{\mathrm{i}}-\mathrm{UWS}+T_{\text {out }}-T_{\text {in }}$,

where GWN is the groundwater abstraction need $\left(\mathrm{Mm}^{3} \mathrm{yr}^{-1}\right)$, WD $\mathrm{i}$ the initial water deficit $\left(\mathrm{Mm}^{3} \mathrm{yr}^{-1}\right)$, UWS useful water surplus $\left(\mathrm{Mm}^{3} \mathrm{yr}^{-1}\right), T_{\text {out }}$ the water transferred out of the catchment $\left(\mathrm{Mm}^{3} \mathrm{yr}^{-1}\right)$, and $T_{\text {in }}$ the water transferred into the catchment $\left(\mathrm{Mm}^{3} \mathrm{yr}^{-1}\right)$.

The water to be abstracted from the groundwater per subcatchment corresponds to the groundwater abstraction needs. Based on the amount of groundwater abstraction needs, a number of wells were placed over the sub-catchments based on the topography; places near cities and irrigation areas were also a target for the well locations. Rock formations with higher borehole yield were also used as a criterion for the well locations; however, in many cases it was not possible to avoid placing wells in low borehole yield regions as these were found to be the most dominant formation in the subcatchment - for instance, the White River. Then model simulations were performed to test whether the amounts of water can be abstracted. Finally, for an extremely severe drought, more severe than the most severe drought registered in the last 50 years, model simulations were carried out for different scenarios. For such a severe drought precipitation would be less, consequently recharge would be reduced and water demand would be higher. Therefore, four simulation scenarios (Table 4) were proposed where baseline recharge (between 1992 and 1995) was reduced and well abstractions linearly increased. These scenarios of recharge values mimic extremely severe drought conditions.

\section{Results and discussion}

\subsection{Results of drought classification}

\subsubsection{Drought classification over time}

The results of the SPI and SRI of 12-month scale indicated that droughts occurred during 1966, 1978, 1983, 1992-1995, and 2003-2004 (Fig. 3). In other words, in the 50 years from 1960 to 2011, six droughts occurred. Results of the drought severity for Elands River sub-catchment (station X2H015) 


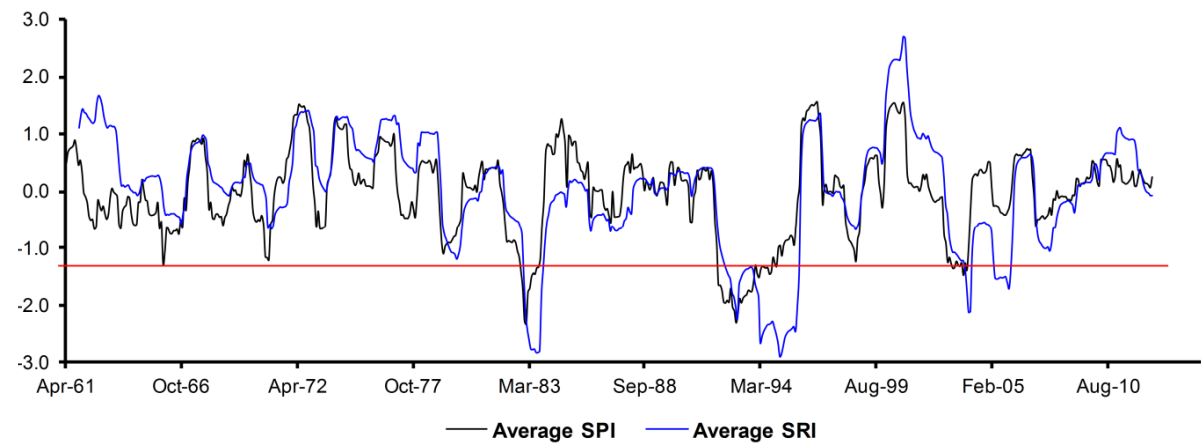

Figure 3. Average SPI and SRI (12-month scale).
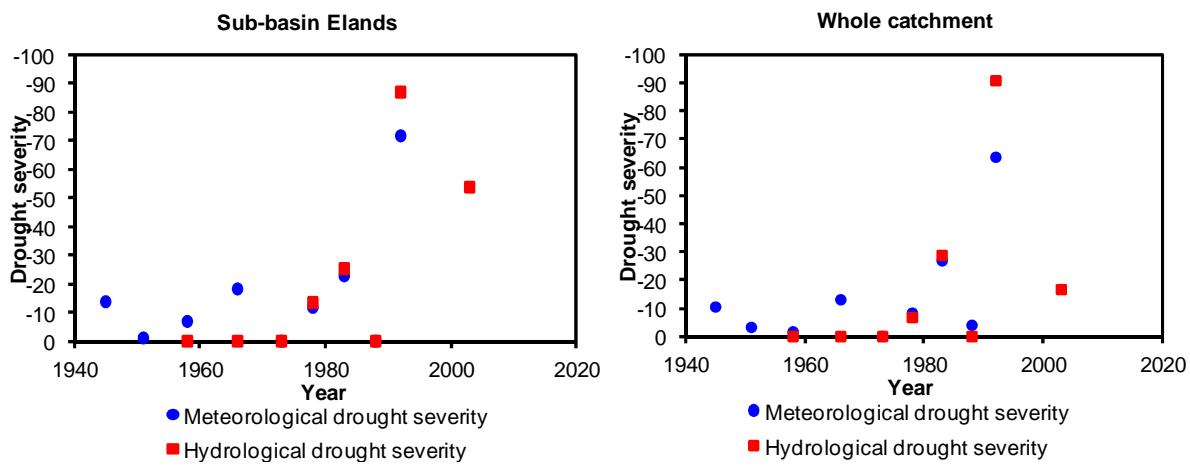

Figure 4. Drought severity in sub-catchment Elands and the whole catchment.

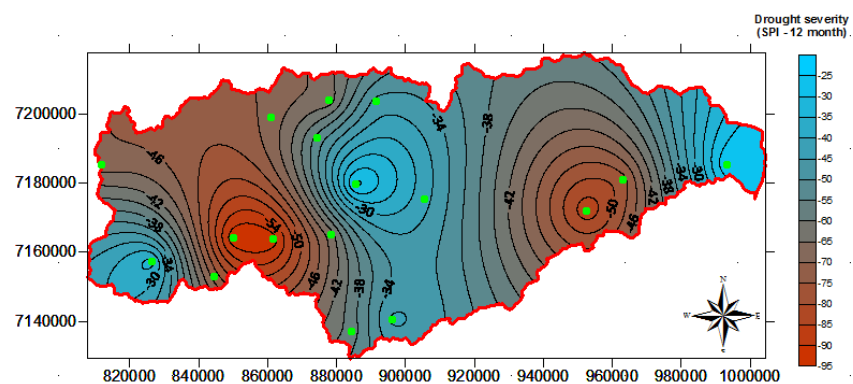

Figure 5. Distribution of the meteorological drought severity during the 1992-1995 drought.

and Crocodile catchment outlet (X2H016) are shown in Fig. 4 as examples.

Three severe droughts occurred in 1983, in 1992-1995, and in 2003-2004. These droughts were also noticed in most of South Africa and neighbouring countries. The most severe one was the 1992-1995 drought, which lasted 4 years. This drought can be classified as severely dry as a meteorological drought and extremely dry as a hydrological drought. It appears from Fig. 4 that the severity of meteorological drought (SPI) used to be higher than the severity of the hydrological drought (SRI) before 1975. But after 1975 the hydrological drought severity is higher than the meteorological drought severity. This can be explained by the increasing abstractions

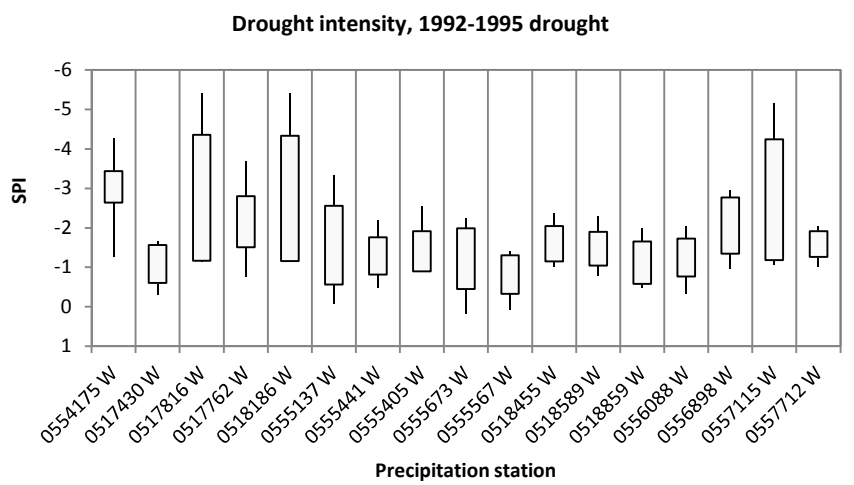

Figure 6. Meteorological drought intensity during the 1992-1995 drought.

of water from the rivers for agricultural, domestic and industrial consumption.

\subsubsection{Drought classification over the catchment}

Figure 5 presents the 1992-1995 meteorological drought severity over the Crocodile catchment. Figure 6 shows the variability of the drought index (SPI) during the drought duration over the catchment. The plot shows for each station the minimum, maximum, standard deviation and average SPI (drought intensity) during 1992-1995. 


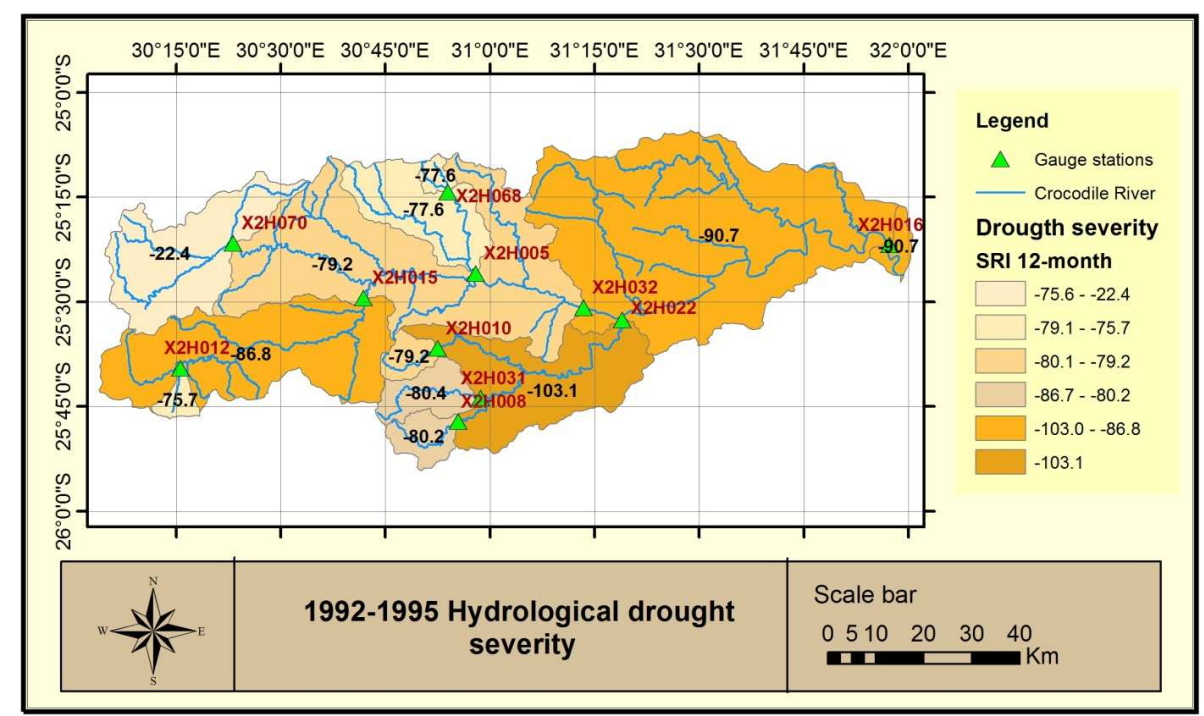

Figure 7. Spatial variability of the hydrological drought severity during the 1992-1995 drought.

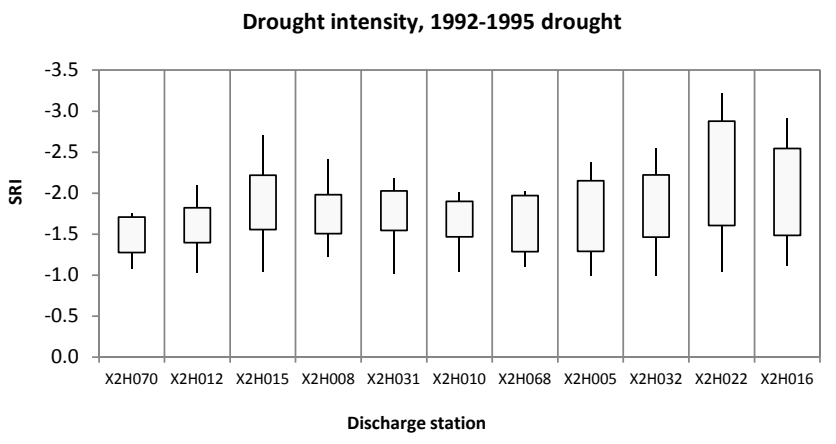

Figure 8. Hydrological drought intensity during the 1992-1995 drought.

The more severe droughts occur in the upstream and downstream areas of the catchment while the middle part of the catchment shows low drought severity. Similarly, the upstream and downstream precipitation stations show high variability of the drought index reaching very high and very low values of SPI. The maximum value of SPI reached in this drought was -5.5 in two stations upstream and one station downstream. On the other hand, the stations in the middle part of the catchment show less variability of SPI during the drought duration where the maximum value of SPI was around -2.5 .

The variation of the hydrological drought severity for each sub-catchment is shown in Fig. 7. Figure 8 shows the variability of the hydrological drought index during the drought duration over the entire catchment; it follows the same spatial pattern of variation as for the meteorological drought intensity presented in Fig. 5.

The hydrological drought severity does not depend only on amount of rainfall; it is also affected by the amount of wa- ter abstracted from the river. Therefore, sub-catchments with less rainfall and high water requirements are the most affected by droughts. For instance, the Kaap catchment (gauging station X2H022) and the Lower Crocodile catchments (gauging station $\mathrm{X} 2 \mathrm{H} 016$ ), which are located in low-rainfall regions and have very high water requirements, are the most vulnerable to droughts and present high drought severity: -90.7 and -103.1 for the Lower Crocodile and Kaap, respectively. On the other hand, the Kwena sub-catchment is less affected by the hydrological drought: the hydrological drought severity is around -22.4. It has less water requirements, and in addition its discharge station (X2H070) is located downstream of the major dam of the Crocodile River (the Kwena dam). Therefore, the dam's operation to keep the flows at regulated levels together with the low water requirements contributes significantly to its low vulnerability to droughts.

The hydrological drought severity on the other small upstream catchments, such as stations X2H012, X2H008, $\mathrm{X} 2 \mathrm{H} 068$ are more dependent on precipitation. On the other hand, the severity on the downstream stations which drain bigger areas (X2H015, X2H022, X2H016) are not only affected by precipitation but are also highly affected by the increased water abstraction from the river for irrigation, domestic and industrial use, thus presenting very high values of hydrological drought severity. Accordingly, most upstream discharge stations have less variability on the SRI, and the downstream stations present high variability of SRI and higher drought intensity. The maximum SRI reached by most upstream sub-catchments is -2.1 and the maximum SRI reached by the downstream stations is -3.2 . It seems that the sub-catchment water transfers do not have much influence on the drought severity. 


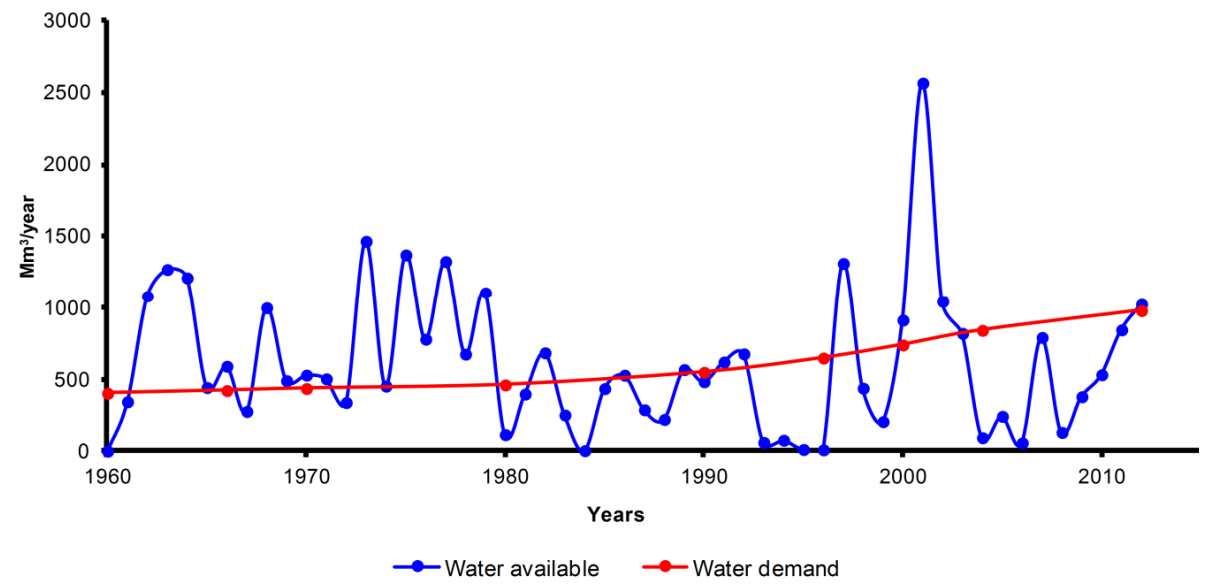

Figure 9. Water available versus water demand for the whole catchment.

Table 5. Irrigation water requirements and water deficit per sub-catchment for the 1992-1995 drought.

\begin{tabular}{lccc}
\hline Sub-catchment & $\begin{array}{c}\text { Irrigation requirements } \\
\left(\mathrm{Mm}^{3} \mathrm{yr}^{-1}\right)\end{array}$ & $\begin{array}{c}\text { Water deficit before applying existing } \\
\text { drought mitigation plan }\left(\mathrm{Mm}^{3} \mathrm{yr}^{-1}\right)\end{array}$ & $\begin{array}{c}\text { GW abstraction needs after applying } \\
\text { existing drought mitigation } \mathrm{plan}\left(\mathrm{Mm}^{3} \mathrm{yr}^{-1}\right)\end{array}$ \\
\hline Kwena & 6.43 & 0 & 0 \\
Elands & 12.47 & 0 & 0 \\
Nelspruit & 22.83 & -8.1 & 21.0 \\
White River & 17.58 & -35.5 & 24.0 \\
Kaap & 80.3 & -12.8 & 10.4 \\
Middle Crocodile & 55.18 & -15.4 & 24.6 \\
Lower Crocodile & 196.48 & -88 & 97.0 \\
\hline Whole catchment & 391.27 & -159.8 & \\
\hline
\end{tabular}

\subsection{Water deficit and groundwater abstraction}

The total water available versus water demand in the whole catchment since 1960 is presented in Fig. 9. The total irrigated area in the Crocodile River catchment is $466.5 \mathrm{~km}^{2}$ which corresponds to around $4.5 \%$ of the catchment. The main crops are sugarcane, vegetables and citrus, occupying about 44,31 and $20 \%$ of the total irrigated area, respectively. The remaining $5 \%$ is occupied by maize which is mostly cultivated in the upper region. Results of the irrigation water requirements per sub-catchment are presented in Table 5. The sub-catchment which presents the highest demand in terms of irrigation is the Lower Crocodile; it demands around 50\% of the total irrigation requirements in the catchment and it is part of the driest area of the catchment. The variation of the irrigation water demand over the year (Fig. 8) does not change according to the season, as it depends on many factors, mainly precipitation, evaporation and crop type. The crop factor varies with the crop type, cropping pattern and plant development - for instance, vegetables are only planted in winter (between March and August) thus requiring water only in this period, while sugarcane exists in the whole year but requires more water during the hot season. There- fore, there is no correlation between evaporation or temperature and the total irrigation water demand. However, it can be noted that despite the low evaporation between April and September, the average irrigation water requirement during this period is slightly higher than the irrigation average water requirement during October and March. This is mainly due to the low precipitation in this period that coincides with the low-temperature season.

The annual domestic and industrial water requirements in the Crocodile catchment are 95 and $22.4 \mathrm{Mm}^{3} \mathrm{yr}^{-1}$, respectively (DWAF, 2009). The Water Use Agreement (TPTC, 2002) signed between Mozambique, South Africa and Swaziland stipulated that the Incomati River should maintain a minimum flow of $2.6 \mathrm{~m}^{3} \mathrm{~s}^{-1}$ average over a 3day period in Ressano Garcia (in Mozambique). Thus, they recommended that a minimum of $1.2 \mathrm{~m}^{3} \mathrm{~s}^{-1}$ should be maintained by the Crocodile River and $1.4 \mathrm{~m}^{3} \mathrm{~s}^{-1}$ should be maintained by the Komati River system. The annual water requirements for domestic and industrial supply were distributed equally per month and per sub-catchment. The transboundary flow requirement was distributed per subcatchment based on the percentage distribution of annual dis- 
Table 6. Groundwater model calibration results.

\begin{tabular}{lrrrrr}
\hline & $\begin{array}{r}\text { Recharge } \\
\left(\mathrm{Mm}^{3} \mathrm{yr}^{-1}\right)\end{array}$ & $\begin{array}{r}\text { Net recharge } \\
\left(\mathrm{Mm}^{3} \mathrm{yr}^{-1}\right)\end{array}$ & $\begin{array}{r}\text { Simulated base } \\
\text { flow }\left(\mathrm{Mm}^{3} \mathrm{yr}^{-1}\right)\end{array}$ & $\begin{array}{r}\text { Observed base } \\
\text { flow }\left(\mathrm{Mm}^{3} \mathrm{yr}^{-1}\right)\end{array}$ & $\begin{array}{r}\% \\
\text { Difference }\end{array}$ \\
\hline Kwena & 97.15 & 99.39 & 55.74 & 54.97 & $1.4 \%$ \\
Elands & 141.78 & 162.90 & 127.25 & 126.18 & $0.8 \%$ \\
Nelspruit & 103.73 & 102.45 & 45.09 & 45.19 & $-0.2 \%$ \\
White River & 21.98 & 24.48 & 10.01 & 9.91 & $1.0 \%$ \\
Kaap & 21.80 & 54.28 & 61.20 & 61.32 & $-0.2 \%$ \\
Middle Crocodile & 68.67 & 66.85 & 196.43 & 197.90 & $-0.7 \%$ \\
Lower Crocodile & 21.98 & 18.67 & 32.87 & 32.56 & $0.9 \%$ \\
Whole catchment & 477.07 & 529.01 & 528.59 & 528.04 & $0.1 \%$ \\
\hline
\end{tabular}

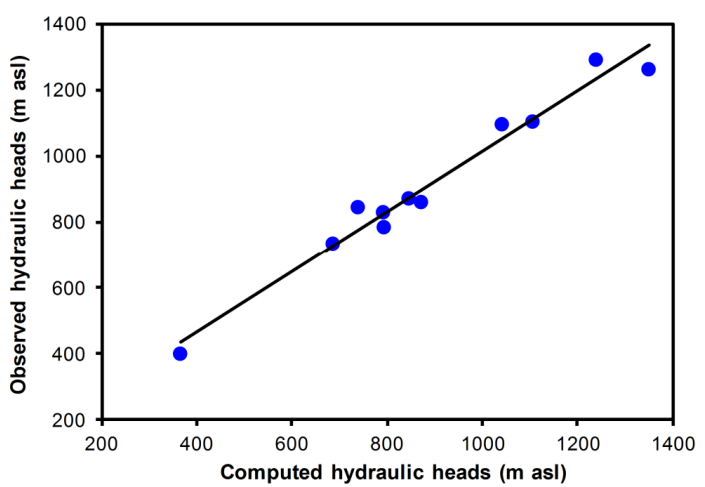

Figure 10. Scatter plot of the computed and observed groundwater heads.

charge of each sub-catchment and further distributed equally per month.

Results of the water deficit computation (Table 5) show that the most stressed sub-catchments are those located in the downstream area where precipitation is lower, evapotranspiration is higher and there is higher irrigation water demand. The upper catchments Kwena and Elands did not present any water deficit in this period due to low water requirements. The total water deficit of the catchment, in the drought period, is estimated to be to $159.8 \mathrm{Mm}^{3} \mathrm{yr}^{-1}$.

A water surplus in the wet season of around $57.1 \mathrm{Mm}^{3} \mathrm{yr}^{-1}$ was obtained for the Kwena and White River catchments. Results show that the use of the existing drought mitigation plan (see Table 3), roughly, would reduce the water deficit from 159.8 to $97 \mathrm{Mm}^{3}$, a reduction of $40 \%$. This shows the critical importance of using an additional source of water to cope with this hazard - a key role that groundwater resources could play. The groundwater requirements for combating drought are listed in Table 5.

\section{Results of groundwater modelling}

The calibration of the steady groundwater flow model resulted in a good agreement between measured and com- puted groundwater levels with $R^{2}$ of 0.96 and Nash-Sutcliffe efficiency of 0.97 (Fig. 10). The simulated base flow per sub-catchment fits the observed base flow (Table 6), which was separated using the HYSEP software (Sloto and Crouse, 1996). The net recharge represents the actual recharge; it is the recharge from precipitation plus the river leakage into the groundwater storage minus the evaporation from the groundwater storage. During the drought period the total net recharge for the whole catchment was found to be $529 \mathrm{Mm}^{3} \mathrm{yr}^{-1}$ which corresponds to $50 \mathrm{~mm} \mathrm{yr}^{-1}$, around $8 \%$ of the total annual precipitation during drought. According to the groundwater study which covers the Crocodile area (WRC, 2005), the long-term annual average recharge in the Crocodile catchment is around $77.9 \mathrm{~mm} \mathrm{yr}^{-1}$ which corresponds to $9 \%$ of the long-term average rainfall in the region. Thus, the percentage of recharge from precipitation of this research and the WRC (2005) study are very close.

The calculated groundwater level contour lines generally follow the topography of the catchment. Groundwater level is deeper in the high mountains within the catchment and shallower in plane areas such as the downstream region. The river is mainly fed by the aquifer; only in few areas as in the higher mountains is the aquifer fed by the river. Water budget results show that the principal input of water in the groundwater storage is the recharge from precipitation $\left(479.52 \mathrm{Mm}^{3} \mathrm{yr}^{-1}\right)$. Evaporation from the groundwater storage $\left(120.26 \mathrm{Mm}^{3} \mathrm{yr}^{-1}\right)$ is low compared to the recharge given the fact that the groundwater table is deep $(>5 \mathrm{~m})$ in many parts of the catchment. 


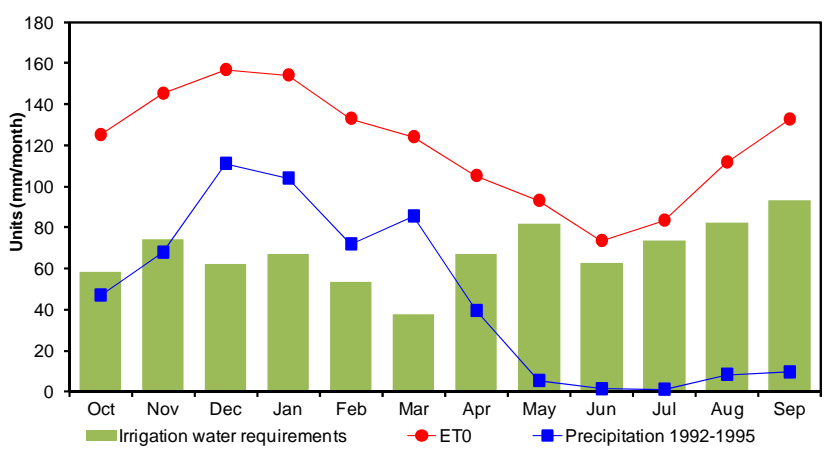

Figure 11. Irrigation water requirements during drought period 1992-1995 for the whole catchment.

\section{Feasibility of using groundwater as an emergency source}

\subsection{Use of groundwater in a drought period (1992-1995 drought)}

Transient abstraction simulations were performed by assigning well abstraction rates equal to the groundwater abstraction needs per sub-catchment listed in Table 5 and as shown in Fig. 11. Results show that if $97 \mathrm{Mm}^{3}$ of water is abstracted per year, then river base flow for the whole catchment would reduce only by $3.1 \%\left(16.51 \mathrm{Mm}^{3} \mathrm{yr}^{-1}\right)$, meaning that it is possible to use the groundwater as an emergency source for drought mitigation. However, looking at the results in a subcatchment scale, the most affected sub-catchments in terms of reduction of base flow, as expected, are the drier subcatchments: White River, Kaap and Lower Crocodile. The most affected is the White River with a base flow reduction of $18 \%$. The other catchments present a base flow reduction of around $8 \%$. However, it is still feasible to abstract water in these sub-catchments. The groundwater levels in Kwena and Elands sub-catchments do not change because there are no abstractions in these sub-catchments while a maximum water table drawdown of around $4 \mathrm{~m}$ can be observed in the other catchments where there are abstractions, except for White River catchment where drawdown reach values of around $20 \mathrm{~m}$.

\subsection{Use of groundwater in case of extremely severe drought}

The four scenarios of using groundwater in the case of extremely severe drought proposed in Table 4 were simulated with the transient groundwater flow model. The model simulation period consists of 4 drought years (taking 1992-1995 drought as reference) followed by 11 normal years. Groundwater is abstracted during the drought years, but switched off during the normal years. The monthly stress period is used to consider seasonal variation of groundwater recharge. Model simulation results were analysed for the maximum

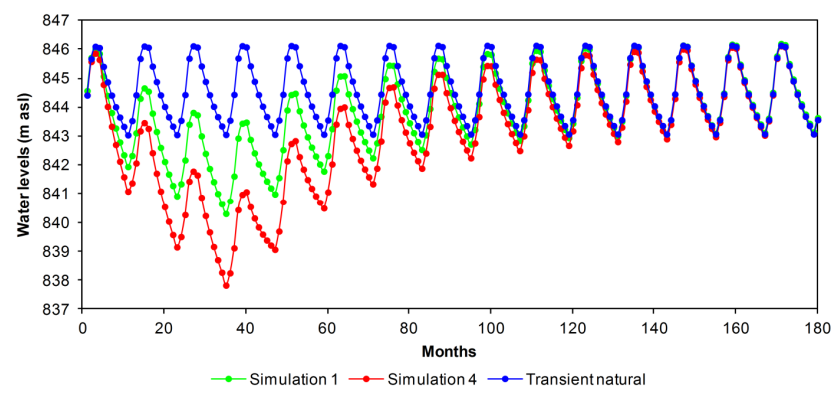

Figure 12. Simulated groundwater levels in well observation AC00232 at White River catchment.

drawdown and reduction of base flow and compared the natural groundwater flow model, a model where abstraction wells are not taken into account. For the simulation scenario 1, the base flow reduction is low; it varies between 2.4 and $8.6 \%$ for the sub-catchments, except in White River where base flow reduction is around $18 \%$. In the most extreme situation of simulation scenario 4, base flow reduction is higher: $12.2,12.5,20.1,11.3$ and $21.1 \%$ in Kwena, Elands, Kaap, Middle Crocodile and Lower Crocodile, respectively - and even much higher in the White River and Nelspruit subcatchments where the base flow reduction is 28.8 and $58.6 \%$, respectively. Figure 12 shows the decrease of groundwater levels for the observation wells located in White River as example. A maximum drawdown of 1.2, 3.5 and $10 \mathrm{~m}$ was observed after 3 years in Kwena, Elands and Kaap subcatchments, respectively, in the simulation scenario 4. However, in sub-catchments White River and Nelspruit the drawdowns are very high, and the worse case is the White River. The drawdowns reach values of 28,36 and $49 \mathrm{~m}$ in simulation scenarios 2, 3 and 4, respectively after 3 years of abstraction. This happens due to the fact that these two subcatchments are mainly constituted by intergranular and fractured aquifer type with low permeability. This high drawdown besides affecting the agricultural activity causes a decrease in the river flows, thus reducing the water availability to less than $50 \%$ in simulation scenario 4 for the White River catchment (see Fig. 13). Briefly, results of the abstraction simulations for the different scenarios show that in most of the sub-catchments it is possible to use the groundwater water for drought mitigation in case of extremely severe droughts. Groundwater levels would recover back to predrought situation when emergency wells are switched off after the drought. However, groundwater exploitation in White River and Nelspruit sub-catchments is limited due to very high drawdowns and, consequently, high river flow reduction during the drought. 

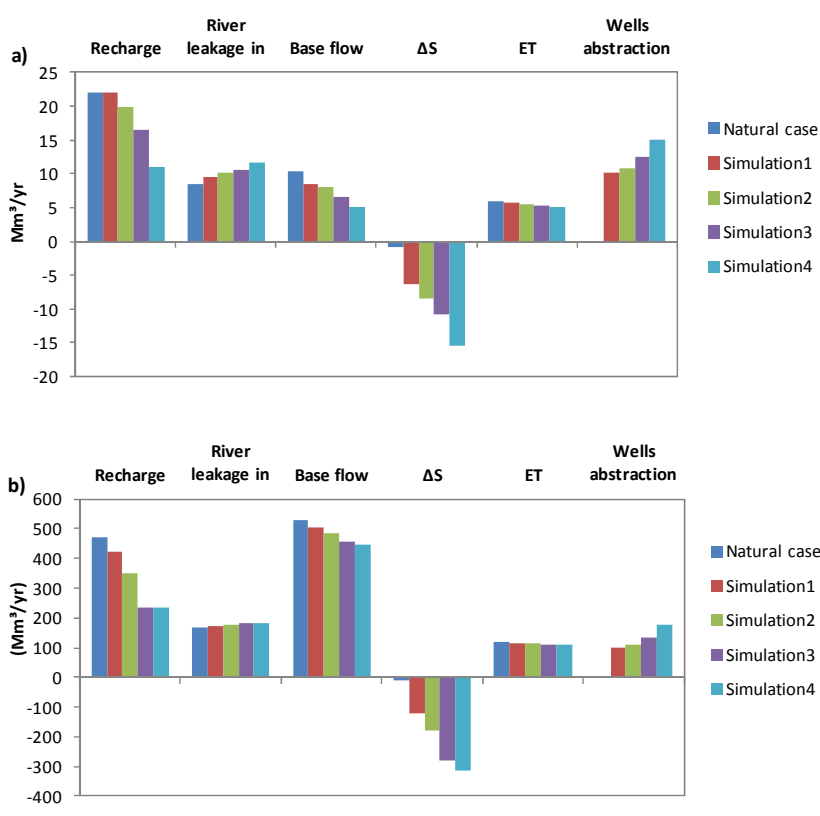

Figure 13. Water balance components of 4 simulation scenarios for (a) White River and (b) whole catchment.

\section{Conclusions}

Several severe droughts occurred in the Crocodile catchment over more than 50 years from 1960 to 2011 . The most severe drought was the 1992-1995 drought. There are spatial differences in drought severity and intensity. The lower and upper catchments show high meteorological drought severity, while the middle catchment shows low meteorological drought severity. The hydrological drought severity is not only affected by meteorological drought, but also affected by human interventions on the catchment. Thus, the hydrological drought severity is higher in the most water-stressed sub-catchments, such as the Kaap and Lower Crocodile and is lower in the less water stressed catchments such as Kwena where the flows are regulated by the Kwena dam, reducing the severity of droughts. It was found that before 1975 the meteorological drought severity was higher than the hydrological drought severity. In contrast, after 1975 the hydrological drought severity is higher than the meteorological drought severity. This shift could be due to increased water consumption in the catchment by forestry, irrigation and domestic use over time.

The water balance study of the catchment shows that the total water deficit during a severe drought (such as the 1992-1995 drought) amounts to up to $159.8 \mathrm{Mm}^{3} \mathrm{yr}^{-1}$, and the most stressed sub-catchments are the Lower Crocodile, Kaap, White River, Nelspruit and Middle Crocodile. Taking into account the existing drought mitigation plan (water storage and inter-basin transfers) this water deficit reduces only by about $40 \%$ to $97 \mathrm{Mm}^{3} \mathrm{yr}^{-1}$. This shows that it is important to consider the use of groundwater to mitigate the droughts. Groundwater abstraction simulation reveals that it is possible to use the groundwater as an emergency source of water to mitigate the drought hazards in the Crocodile River catchment. In general, the Kaap, Middle Crocodile and Lower Crocodile sub-catchments are most feasible for groundwater exploitation while the groundwater exploitation in Nelspruit and White River catchments is restricted due to high river flow reduction and high drawdown during the drought.

This case study demonstrates that conjunctive water management of groundwater and surface water resources is necessary to mitigate the impacts of droughts. This needs a multi-method approach including coupled modelling of surface water and groundwater fluxes, in which the detailed geological features of the study area are taken into account, as well as a long time series of groundwater levels which are crucial for good model calibration.

Acknowledgements. We gratefully acknowledge the partial funding for the field research and paper writing provided through the RISKOMAN and the RISKOMAN-GAM projects funded by DGIS/UNESCO-IHE Programmatic Cooperation (DUPC). Additional support for preparing this paper from DEWFORA project which is funded by the Seventh Framework Programme for Research and Technological Development (FP7) of the European Union (Grant agreement no. 265454) is also gratefully acknowledged. We are also very grateful to the groundwater department of DWAF (Department of Water Affairs and Forestry), SAWS (South African Weather Service) and ICMA (Incomati Catchment Management Agency) in South Africa for the data provided.

Edited by: F. Pappenberger

\section{References}

Alliance, T. L.: Longleaf pine root system, available at: http://www.auburn.edu/academic/forestry_wildlife/ longleafalliance/ecosystem/longleaftree/longleaftree $3 . \mathrm{htm}$ (last access: 15 January 2013), 2002.

Baron, J., Seward, P., and Seymour, A.: The Groundwater Harvest Potential Map of the Republic of South Africa, Department of Water Affairs and Forestry, Pretoria, South Africa, Gh 3917, 1998.

Baykan, N. O. and Özçelik, C.: Management of drought, Water resources management: Risks and Challenges for the 21st century, Turkey, 55-62, 2006.

Consultec and BKS: Joint Inkomati Basin Study, Direção nacional de águas, Maputo, Mozambique, Consultec Report No. C1499MRF, BKS ACRES Report No. P8491/08, 2001.

DWA: Water Requirements and Availability Reconciliation Strategy for the Mbombela Municipal Area, Department of Water Affairs, Pretoria, South Africa, 2013.

DWAF: Groundwater Resources Assessment II - Recharge Final Report, Department of Water Affairs and Forestry, South Africa, 2006. 
DWAF: Hydrology of the Crocodile River Department of Water Affairs and Forestry, Pretoria, South Africa, PWMA 05/X22/00/1508, 2009.

Food and Agriculture Organization of the United Nations (FAO): Irrigation potential in Africa, Land and Water Bulletin, 4, FAO, Rome, Italy, available at: http://www.fao.org/docrep/W4347E/ W4347E00.htm, 1997.

Fischer, S., Witthüser, K., Birke, M., Leyland, R., and Schneider, M.: Regional description of the groundwater chemistry of the Kruger National Park (KNP) using multivariate statistics, Groundwater Conference 2009, Somerset West, South Africa, 16 November, 2009.

Fischer, S., Witthüser, K., Birke, M., Leyland, R., and Schneider, M.: Describing the groundwater system of the Kruger National Park (South Africa) on the basis of hydrogeochemical methods and multivariate statistical algorithms, Schriftenreihe der Deutschen Gesellschaft für Geowissenschaften, Germany, 41 pp., 2010.

Fundisi, D., Riddell, E. S., and Lorentz, S. A.: Hydrological connectivity in selected pristine catchments in the Kruger National Park, 16th SANCIAHS National Hydrology Symposium, University of Pretoria, South Africa, 1-3 October, 2012.

Guttman, N. B.: Comparing the Palmer Drought Index and the Standardized Precipitation Index, J. Am. Water Resour. Assoc., 34, 113-121, doi:10.1111/j.1752-1688.1998.tb05964.x, 1998.

IPCC: Climate Change 2013: The Physical Science Basis, Contribution of Working Group I to the Fifth Assessment Report of the Intergovernmental Panel on Climate Change, edited by: Stocker, T. F., Qin, D., Plattner, G.-K., Tignor, M., Allen, S. K., Boschung, J., Nauels, A., Xia, Y., Bex, V., and Midgley, P. M., Cambridge University Press, Cambridge, United Kingdom and New York, NY, USA, 1535, 2013.

Leyland, R. C. and Witthüser, K. T.: Regional Description of the Groundwater Chemistry of the Kruger National Park, Water Research Commission, Pretoria, South Africa, 19 pp., 2008.

Loucks, D. and Beek, E. V.: Water Resources systems Planning and Management - An Introduction to Methods, Models and Aplications, United Nations Educational, Paris, France, 581-599, 2005.

Lynch, S. D.: Development of a raster database of annual, monthly and daily rainfall for Southern Africa, Water Research Commision, Pretoria, South Africa, 78 pp., 2003.

MacDonald, G. M.: Severe and sustained drought in southern California and the West: Present conditions and insights from the past on causes and impacts, Quatern. Int., 173, 87-100, doi:10.1016/j.quaint.2007.03.012, 2007.

Matheron, G.: Principles of Geostatistics, Economic Geol., 58, 1246-1266, 1963.

McCabe, G. J. and Markstrom, S. L.: A Monthly Water-Balance Model Driven By a Graphical User Interface, US Geological Survey Open-File Report 2007-1088, Reston, Virginia, USA, 6 pp., 2007.

McDonald, M. G. and Harbaugh, A. W.: A modular threedimensional finite difference groundwater flow model, US Geological Survey Open-File Report 83-875, Reston, Virginia, 528 pp., 1983.

McKee, T. B., Doesken, N. J., and Kleist, J.: The relation of drought frequency and duration to time scales, 8th Conference on Applied Climatology, Anaheim, California, 17-22 January, 1993.
Mishra, A. K. and Singh, V. P.: A review of drought concepts, J. Hydrol., 391, 202-216, doi:10.1016/j.jhydrol.2010.07.012, 2010.

Murphy, S. R.: Tropical perennial grasses - root depths, growth and water use efficiency, NSW Department of Primary Industries, Primefacts, 1027, 2010.

Niekerk, A. V., Nel, J., and Riddell, E.: Conceptualizing groundwater distribution over different spatial and geological scales using electrical resistivity profiles within the Kruger National Park, 16th SANCHIAS National Hydrology Symposium University of Pretoria, South Africa, 1-3 October 2012, 1-10, 2012.

Nonner, J. C.: Introduction to hydrogeology, CRC Press, Taylor and Francis Group, Leiden, the Netherlands, 258 pp., 2010.

Palmer, W.: Meteorological drought, Volume Res. paper No. 45: Washington, Department of Commerce, 58 pp., 1965.

Palmer, W.: Keeping Track of Crop Moisture Conditions, Nationwide: The New Crop Moisture Index, Weatherwise 21, 156-161, doi:10.1080/00431672.1968.9932814, 1968.

Pavelic, P., Srisuk, K., Saraphirom, P., Nadee, S., Pholkern, K., Chusanathas, S., Munyou, S., Tangsutthinon, T., Intarasut, T., and Smakhtin, V.: Balancing-out floods and droughts: Opportunities to utilize floodwater harvesting and groundwater storage for agricultural development in Thailand, J. Hydrol., 470-471, 55-64, doi:10.1016/j.jhydrol.2012.08.007, 2012.

Rockström, J.: Resilience building and water demand management for drought mitigation, Phys. Chem. Earth A/B/C, 28, 869-877, doi:10.1016/j.pce.2003.08.009, 2003.

Shukla, S. and Wood, A. W.: Use of a standardized runoff index for characterizing hydrologic drought, Geophys. Res. Lett., 35, L02405, doi:10.1029/2007g1032487, 2008.

Sienze, F. and Jahnke-Bornemann, A.: Climate indices, available at: http://icdc.zmaw.de/climate_indices.html?\&L=1 (last access: 15 January 2013), 2012.

Sims, A. P., Niyogi, D. D. S., and Raman, S.: Adopting drought indices for estimating soil moisture: A North Carolina case study, Geophys. Res. Lett., 29, 24-31, 2002.

Sloto, R. A. and Crouse, M. Y.: HYSEP: a computer program for streamflow hydrograph separation and analysis, US Geological Survey Water-Resources Investigations Report 96-4040, 46 pp., 1996.

Smith, M.: Manual for CROPWAT version 5.2, FAO: Rome, Italy, 45 pp., 1988.

Tanner, A., and Mauritius, A.: Tripartite Permanent Technical Committee (TPTC), Moçambique, South Africa, Swaziland - Baseline Evaluation and Scoping Report, Progressive Realisations of the Incomaputo Agreement (PRIMA), Maputo, Mozambique, 167 pp., 2010.

Tnco-Maputo Tripartite Permanent Technical Committee (TPTC): Interim IncoMaputo Water Use Agreement, Ministry of public works and housing: Direcção Nacional De Águas, Maputo, Mozambique, 28 pp., 2002.

Vegter, J. R.: Groundwater Resources of the Republic of South Africa - Sheet 1 and Sheet 2, Water Research Commission, Pretoria, South Africa, 1995.

Water Systems Management: Water Resources Situation Assessment: Ground Water Resources of South Africa, Department of Water Affairs and Forestry, Pretoria, South Africa, 2001.

Werick, W. J., Willeke, G. E., Guttman, N. B., Hosking, J. R. M., and Wallis, J. R.: National drought atlas developed, 
Eos, Transactions American Geophysical Union, 75, 89-90, doi:10.1029/94eo00706, 1994.

Willeke, G.: The National Drought Atlas, US Army Corps of Engineers, Water Resources Support Center, Institute for Water Resources, Report 94-NDS-4, 1994.

WRC: Water Resources of South Africa, Water Research Comission, Pietermaritzburg, South Africa, K5/1491, 2005.

Zaag, P. V. D. and Vaz, Á. C.: Sharing the Incomati waters: cooperation and competition in the balance, IWA Publishing, London, UK, 5, 349-368, 2003.
Zargar, A., Sadiq, R., Naser, B., and Khan, F. I.: A review of drought indices, Environmental Reviews, 333-349, doi:10.1139/a11-013, 2011.

Zhou, Y., Wang, L., Liu, J., and Ye, C.: Impacts of drought on groundwater depletion in the Beijing Plain, China, in: Climate Change Effects on Groundwater Resources: A Global Synthesis of Findings and Recommendations, edited by: Treidel, H., Martin-Bordes, J. L., and Gurdak, J. J., CRC Press, London, UK, 281-303, 2011. 